\title{
The Application Of The Luftman Method Toward The Alignment Of Business Strategies And IT In Kelapa Dua Sub-district West Jakarta
}

\author{
Rani Irma Handayani $1^{\text {st }}$ \\ Universitas Bina Sarana Informatika \\ rani.rih@bsi.ac.id
}

\author{
Frisma Handayanna $2^{\text {nd }}$ \\ STMIK Nusa Mandiri Jakarta \\ Frisma.fha@nusamandiri.ac.id
}

\author{
Fitri Ratna Sari3 ${ }^{\text {rd }}$ \\ STMIK Nusa Mandiri Jakarta \\ Fitri_ratnasari22@yahoo.co.id
}

\begin{abstract}
The Kelapa Dua West Jakarta is a government agency that has to serve the community every day. In its operational activities, it requires Information Technology (IT) to complete daily operational tasks. Because of this, the west Jakarta sub-district of Kelapa Dua needs an appropriate IT management so that it can serve the community to the fullest. Good IT management is done by assessing the suitability between IT applications and organizational business processes. For this reason, the Luftman method is used to measure the alignment of Business and IT strategies by using six criteria namely Communications, Competency / Value Measurement, Governance, Partnership, Scope \& Architecture, Skill. Overall, all the criteria and maturity of information technology strategies and business strategies in the kelurahan are still at level 2 or at the Commited level so that it can be said that there is no alignment between business strategies and IT strategies.
\end{abstract}

Key field-Luftman's SAMM, Strategic Alignment Maturity Model, aligment strategy, IT Governance Institute

\section{INTRODUCTION}

Information Technology (IT) has a very important influence on the success of the organization to win the competition. The impact of IT is shown by a significant influence on the organization's strategic response in the face of globalization. IT in organizations relates to its role in making IT as part of the organization's strategic response to face free competition, where competition between organizations becomes increasingly sharp.
The choice of a governance model or structure does not mean that the organization has effectively implemented an enabling governance structure and in line with IT and sustains the organization. It is important that organizational leaders and directors understand the relationship and impact of IT governance structures for IT strategic alignment. (Hajikhani 2013).

Management also needs to know the extent to which the IT initiatives that have been carried out have an impact on the organization. Alignment level information not only serves as a tool for management to get the big picture, but also becomes the basis for 
prioritizing new policies in order to improve and improve performance. (Marcel and Yuwono 2013).

Kelurahan kelapa dua west jakarta is a government agency located in West Jakarta. In daily operational activities, Information Technology (IT) is needed in serving the community. The village head is aware of that, so the West Jakarta sub-district of Kelapa Dua needs an appropriate IT management so that it can serve the community to the fullest.

With proper IT management it is expected that the application of information technology can work with optimal. Good IT management is done by assessing the suitability between IT applications and organizational business processes. Therefore the Luftman method is used to measure alignment of Business and IT strategies with using six criteria namely Communications, Competency / Value Measurement, Governance, Partnership, Scope \& Architecture, Skills. (Handayani 2016)

\section{LITERATURE REVIEW}

\section{A. Business and IT Alignment}

According to (Jogiyanto and Willy Abdillah 2011), the application of IT in organizations aims to support the achievement of organizational goals through IT support as an enabler. But not all forms of IT investment generate value for the organization. Empirical facts show that 42 percent of large companies in the USA experience IT paradoxes caused by the inability of organizations to build harmony between IT strategies and business strategies. The same was stated by researchers who examined the impact of IT on organizational performance. Thus, understanding the concepts of business strategy and IT strategy, business-IT alignment concepts, and determinants of business-IT strategy alignment are important issues that should be known by stakeholders, including academics and practitioners.

\section{B. Luftman Model}

Luftman has built a method that can help a company know the level of strategic maturity that the company has. Luftman's method is known as the Luftman Framework or the Luftman strategic alignment maturity model. By knowing the position of maturity of strategic alignment in the company, efforts to minimize the things that are inhibiting factors (inhibitors) and improve the supporting factors (enablers) can be done well.

There are 5 (five) levels of strategic alignment maturity outlined in the Luftman method such as table II.5 below, namely:

1. Initial / Ad Hoc Process
2. Committed Process

3. Established Focused Process

4. Improved / Managed Process

5. Optimized Process

Table 1 : Maturity Levels in Harmony

\begin{tabular}{|c|c|c|}
\hline \multirow{2}{*}{ Level } & Likert Scale Range \\
\cline { 3 - 3 } (average)
\end{tabular}

Source : (Luftman \& Kampaiah 2007

The following is a picture of the six criteria for aligning business strategies and information technology strategies according to Luftman's model, namely:

1. Communication (Communications)

2. Competence / Value of measurement (Competency / Value Measurement)

3. Governance

4. Partnership (Partnership)

5. Scope and architecture (Scope \& Architecture)

6. Skills

\section{DISCUSSION}

The results of the analysis obtained by the authors from the results of research conducted on the condition of the alignment of business strategy maturity and information technology strategy achieved by the Kelapa Dua village based on the results of the instrument in the form of questionnaires can be seen in each criterion. can improve the quality of work.

A. Results of the communication criteria analysis

The following are the results of the respondents' analysis of each criterion: 
Table 2 : The results of respondents maturity alignment communication criteria

\begin{tabular}{|c|c|c|}
\hline Variable / statement & $\begin{array}{l}\text { Total } \\
\text { Value }\end{array}$ & $\begin{array}{c}\text { Total } \\
\text { Maturity } \\
\text { Value }\end{array}$ \\
\hline $\begin{array}{l}\text { The IT used is appropriate } \\
\text { and supports the work } \\
\text { process in the kelurahan }\end{array}$ & 2.33 & \multirow{6}{*}{2.06} \\
\hline $\begin{array}{l}\text { IT is very influential on the } \\
\text { work process (supporting } \\
\text { the performance of all } \\
\text { existing parts) }\end{array}$ & 2.00 & \\
\hline $\begin{array}{l}\text { Information dissemination } \\
\text { or socialization of new } \\
\text { innovations or changes that } \\
\text { occur through } \\
\text { predetermined mechanisms } \\
\text { / procedures (eg meetings, } \\
\text { emails, etc.) }\end{array}$ & 1.67 & \\
\hline $\begin{array}{l}\text { The IT department is } \\
\text { responsive to requests and } \\
\text { provides support for } \\
\text { operational activities (both } \\
\text { routine and incidental } \\
\text { activities) }\end{array}$ & 2.00 & \\
\hline $\begin{array}{l}\text { Knowledge sharing } \\
\text { activities are carried out } \\
\text { formally sharing between } \\
\text { all employees and also with } \\
\text { superiors }\end{array}$ & 2.33 & \\
\hline $\begin{array}{l}\text { Relationship with vendors / } \\
\text { suppliers is controlled and } \\
\text { carried out routinely and } \\
\text { continuously }\end{array}$ & 2.00 & \\
\hline
\end{tabular}

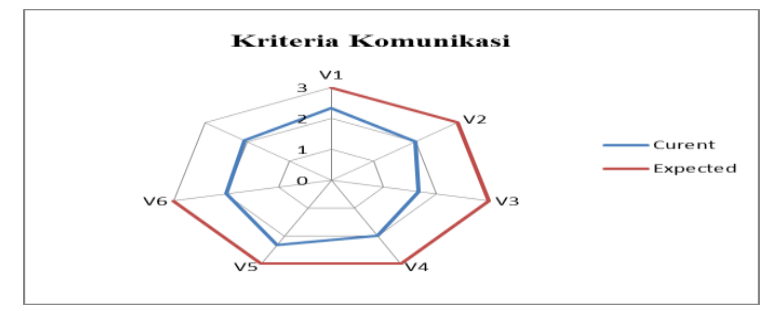

Figure 1 Communication Criteria

In this communication criteria information technology used has supported and influenced the processes of better work activities. IT is very influential and supports every work activity carried out by employees. Share knowledge information in the kelurahan that is running. Trust and openness in implementing business and IT alignment can be done with the existence of a good liaison role and the effectiveness of IT strategy relationships with vendors.

From table 2 above it can be concluded that the average maturity condition of the Kelapa Dua Village on the communication criteria is at level 2 on the maturity of the alignment of business strategies and IT strategies. With this condition it can be seen that there is a good understanding in terms of IT management and business management. Information Technology is very influential on the work process.

Communication between the head of the village head and staff staff is routinely carried out through meetings to evaluate the application of IT in the work process.

\begin{tabular}{|c|c|c|}
\hline Variable / statement & $\begin{array}{l}\text { Total } \\
\text { Value }\end{array}$ & $\begin{array}{c}\text { Total } \\
\text { Maturity } \\
\text { Value }\end{array}$ \\
\hline $\begin{array}{l}\text { IT competency } \\
\text { measurement is done by } \\
\text { measuring cost effectiveness } \\
\text { and involving business } \\
\text { opportunities that can be } \\
\text { generated by IT, staff and } \\
\text { business partners }\end{array}$ & 2.00 & \multirow{7}{*}{1.95} \\
\hline $\begin{array}{l}\text { Competency measurement } \\
\text { from the business side is } \\
\text { carried out based on the } \\
\text { orientation of the lurah's } \\
\text { interests to employees / } \\
\text { subordinates }\end{array}$ & 2.33 & \\
\hline $\begin{array}{l}\text { Measurement of } \text { business } \\
\text { competencies, } \\
\text { partners and IT a ares } \\
\text { interconnected with each } \\
\text { other }\end{array}$ & 2.33 & \\
\hline $\begin{array}{l}\text { The implementation of the } \\
\text { Service Level Agreement } \\
\text { has been implemented in an } \\
\text { integrated manner in all } \\
\text { units }\end{array}$ & 1.67 & \\
\hline $\begin{array}{l}\text { Comparison (benchmarking) } \\
\text { in the framework of } \\
\text { evaluating the output } \\
\text { produced has been done } \\
\text { routinely }\end{array}$ & 1.67 & \\
\hline $\begin{array}{l}\text { General reviews } \\
\text { evaluations and evaluations } \\
\text { of IT investments have been } \\
\text { carried out regularly }\end{array}$ & 2.00 & \\
\hline $\begin{array}{l}\text { Improvement / improvement } \\
\text { of processes and work } \\
\text { activities that are less } \\
\text { optimal based on the results } \\
\text { of IT investment evaluations } \\
\text { are carried out well and } \\
\text { routinely }\end{array}$ & 1.67 & \\
\hline
\end{tabular}


B. Results from analysis o competency criteria

The results of analysis of respondents on competency criteria can be seen in the following table 3 :

Table 3 : The Results of respondents are alignment

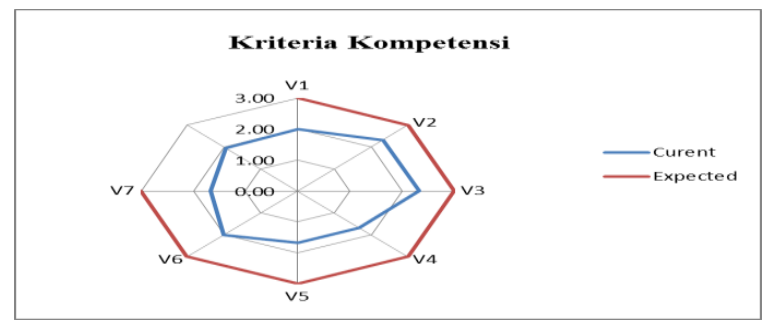

Figure 2

Competency criteria

In this competency criteria, it explains how to understand things that can be evaluated from the process of business and IT alignment in the form of improving the quality of work to assess kelurahan commitment to the use of IT.

From table 3 above, it can be concluded that the average maturity condition of the Kelurahan on the competency criteria is at level 1 on the maturity of the alignment of business strategies and IT strategies. With these conditions, the average of the kelurahan evaluation of the role of IT in the business for the calculation of costs incurred by the kelurahan on the development of IT has not yet arrived at a good condition.

The measurement variables of the business system are still not aligned and measurement of competency has not been oriented towards the interests of the kelurahan and business partners

\section{Results from analysis of governance criteria}

The results of the analysis of respondents on governance criteria can be seen in table 4 below:

Table 4

Results of respondents alignment maturity Governance criteria

\begin{tabular}{|l|c|c|}
\hline \multicolumn{1}{|c|}{ Variable / statement } & $\begin{array}{c}\text { Total } \\
\text { Value }\end{array}$ & $\begin{array}{c}\text { Total } \\
\text { Maturity } \\
\text { Value }\end{array}$ \\
\hline $\begin{array}{l}\text { Business strategy } \\
\text { planning in the kelurahan } \\
\text { has been well integrated }\end{array}$ & 1.67 & \\
\hline $\begin{array}{l}\text { Planning for IT strategies } \\
\text { and Information Systems } \\
\text { in the kelurahan has been } \\
\text { well integrated }\end{array}$ & 2.00 & \multirow{2}{*}{1.79} \\
\hline
\end{tabular}

\begin{tabular}{|l|l|}
\hline $\begin{array}{l}\text { The responsibility and } \\
\text { authority of the IT } \\
\text { department in the } \\
\text { organizational structure }\end{array}$ & 2.00 \\
is under the Head of the \\
Village Head
\end{tabular}

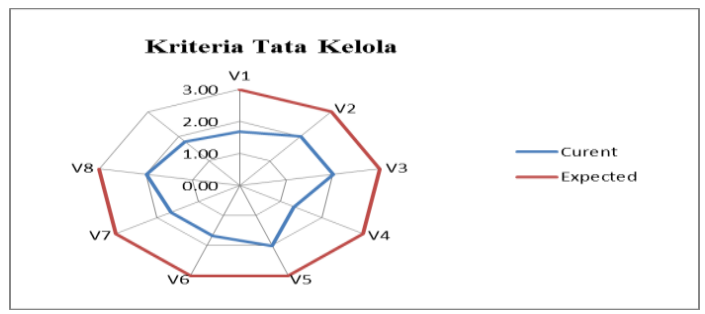

Figure 3

Governance Criteria

Good business strategy planning and urban IT strategy and agreement on authority in the business and IT alignment process.

The maturity level of this governance criterion is where the kelurahan in the kelurahan strategic planning has been integrated into all staff staff and in collaboration with the kelurahan external parties.

From table 4 above, it can be concluded that the average maturity condition of the Kelurahan on the criteria of governance is at level 1. From this maturity condition by looking at the conditions that occur in the kelurahan, for each village head the staff must held a meeting to discuss 
urban village strategic planning. While IT investments are based on efficiency and productivity.

D. Results From the Pertnership Criteria Analysis

The results of the analysis of the respondents on the partnership criteria can be seen in table 5 below:

Table 5 : Results of respondents maturity alignment of partnership criteria

\begin{tabular}{|c|c|c|}
\hline Variable / statement & $\begin{array}{c}\text { Total } \\
\text { Value }\end{array}$ & $\begin{array}{c}\text { Total } \\
\text { Maturity } \\
\text { Value } \\
\end{array}$ \\
\hline $\begin{array}{l}\text { IT is an important asset for } \\
\text { the kelurahan to work with } \\
\text { businesses in creating value } \\
\text { for the kelurahan }\end{array}$ & 2.00 & \multirow{6}{*}{1.89} \\
\hline $\begin{array}{l}\text { With the presence of IT, the } \\
\text { kelurahan is more adaptable } \\
\text { in the face of change }\end{array}$ & 1.67 & \\
\hline $\begin{array}{l}\text { The risk of failure of IT } \\
\text { implementation is borne } \\
\text { together and there is an } \\
\text { appreciation for the successful } \\
\text { implementation of IT together } \\
\text { between management and the } \\
\text { IT department }\end{array}$ & 2.33 & \\
\hline $\begin{array}{l}\text { Management relations } \\
\text { between business and IT have } \\
\text { been implemented and } \\
\text { continuous improvements are } \\
\text { made }\end{array}$ & 1.33 & \\
\hline $\begin{array}{l}\text { The form of trust in internal } \\
\text { relations with business } \\
\text { partners is to trust each other }\end{array}$ & 1.67 & \\
\hline $\begin{array}{l}\text { The Head of the Village Head } \\
\text { is a sponsor in the } \\
\text { development of the kelurahan }\end{array}$ & 2.33 & \\
\hline
\end{tabular}

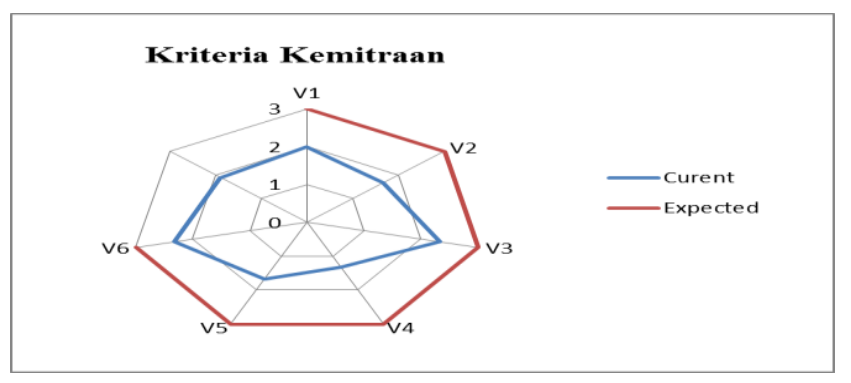

Figure 4 : Partnership Criteria
Contributions in business and IT alignment play a role in the progress of an organization. The relationship between business and IT can enable and encourage change in an organization.

At the maturity level of this partnership criterion, the head of the lurah realizes that information technology can provide added value to the business and has contributed according to business needs.

From table 5 above, it can be concluded that the average maturity condition of the Kelurahan on the criteria of the partnership is at the level of 1 . Judging from this condition, it can be explained that the cooperative relations achieved at this level are not good enough. In the IT kelurahan it is also not considered as an important asset and is also treated to be developed.

E. Results from criteria analysis o scope and architecture

The results of the analysis of respondents on the criteria for scope and architecture can be seen in table 6 below:

Table 6

Results of respondents maturity alignment criteria Scope and Architecture

\begin{tabular}{|l|c|c|}
\hline Variable / statement & $\begin{array}{c}\text { Total } \\
\text { Value }\end{array}$ & $\begin{array}{c}\text { Total } \\
\text { Maturity } \\
\text { Value }\end{array}$ \\
\hline $\begin{array}{l}\text { The role of IT in } \\
\text { supporting urban } \\
\text { business processes as } \\
\text { drivers / enablers in the } \\
\text { village business strategy }\end{array}$ & 2.00 & \\
\hline $\begin{array}{l}\text { Kelurahan has integrated } \\
\text { and standardized } \\
\text { standards in planning and }\end{array}$ & 2.00 & \\
implementing IT & \\
\hline $\begin{array}{l}\text { The IT / SI architecture } \\
\text { that exists in the } \\
\text { kelurahan has been } \\
\text { integrated with business } \\
\text { partners }\end{array}$ & 2.00 & \\
\hline $\begin{array}{l}\text { The treatment given to } \\
\text { the TI / SI architecture as } \\
\text { an enabler is used to } \\
\text { change jobs }\end{array}$ & 2.00 & \\
\hline
\end{tabular}




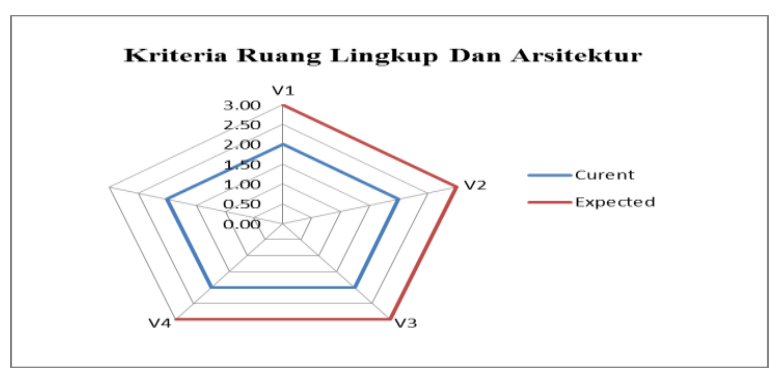

Figure 5 : Criteria for Scope and Architeture

Determine the scope and form of the business and IT alignment process. Determine the scope of alignment and evaluate and apply new technologies that emerge.

Providing flexible infrastructure and transparent explanation to management and employees using IT. Evaluate and implement IT effectively.

The Kelurahan has used IT as a supporter in carrying out the work process in terms of the use of software related to work programs in the kelurahan.

From table 6 above, it can be concluded that the condition of the average maturity of Kelapa Dua Village on the criteria of scope and architecture is at level / level 2 on the maturity of strategy alignment. Seeing the results obtained can be illustrated the condition of the scope and architecture in the Kelapa Dua Village on average has been well integrated.

The architecture that was built has begun to be addressed by considering the benefits that will be obtained

F. Results from expertise criteria analysis

The results of the analysis of respondents on the criteria for scope and architecture can be seen in table 7 below :

Table 7

Results of respondents alignment maturity Expertise criteria

\begin{tabular}{|l|c|c|}
\hline Variable / statement & $\begin{array}{c}\text { Total } \\
\text { Value }\end{array}$ & $\begin{array}{c}\text { Total } \\
\text { Maturity } \\
\text { Value }\end{array}$ \\
\hline $\begin{array}{l}\text { The response to new } \\
\text { innovations is in the } \\
\text { technology section, } \\
\text { good and fast }\end{array}$ & 2.00 & \multirow{2}{*}{1.95} \\
\hline $\begin{array}{l}\text { In carrying out tasks } \\
\text { based on meetings and } \\
\text { discussed together }\end{array}$ & 2.00 & \\
\hline
\end{tabular}

\begin{tabular}{|c|c|}
\hline $\begin{array}{l}\text { Readiness in the face } \\
\text { of changes in height } \\
\text { and focus }\end{array}$ & 1.67 \\
\hline $\begin{array}{l}\text { Opportunities to } \\
\text { improve careers for all } \\
\text { staff staff }\end{array}$ & 2.00 \\
\hline $\begin{array}{l}\text { Provide training to staff } \\
\text { staff according to their } \\
\text { expertise }\end{array}$ & 2.00 \\
\hline $\begin{array}{l}\begin{array}{l}\text { Kelurahan } \\
\text { environment }\end{array} \\
\text { political, religious etc.) } \\
\text { (social, } \\
\text { is very good }\end{array}$ & 1.67 \\
\hline $\begin{array}{l}\text { Kelurahan uses } \\
\text { consultants to plan and } \\
\text { develop IT strategies }\end{array}$ & 2.33 \\
\hline
\end{tabular}

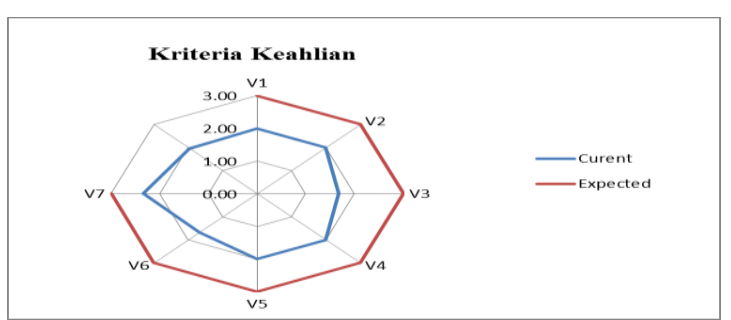

Figure 6

Expertise Criteria

It is a measure of the ability of human resources to support the business and IT alignment process. Among them are the skills of human resources in the organization. And also responds to new innovations related to skills possessed by human resources. So also consider the social, religious and cultural environment in the organization.

Maturity level on this criterion is an organization can be said to be effective by looking at social and cultural environmental factors. And can be improved by providing training for human resources, providing decent wages and providing career opportunities.

From table 7 above it can be concluded that the condition of the average maturity of the Kelapa Dua Village on the criteria of expertise is at level / level 1 on the maturity of strategy alignment. Seeing the results of the expertise criteria at level 1 this illustrates the leadership style that exists in the kelurahan partly still focused on the unit level only and has not been comprehensive in all parts / units. But the kelurahan has known the need to change according to business demands. Capacity building of staff staff through training has been carried out. Kelurahan is responsive to changes that occur in the business environment by applying IT to work activities 


\section{G. Analysis results for all criteria}

The following is a table of 8 analysis results based on answers from respondents for the overall criteria

Table 8

The results of respondents maturity alignment overall criteria

\begin{tabular}{|l|c|c|}
\hline \multicolumn{1}{|c|}{ Criteria } & Maturity & $\begin{array}{c}\text { Total } \\
\text { Maturity }\end{array}$ \\
\hline Communication & 2.06 & \multirow{1}{*}{1.94} \\
\hline Competence & 1.95 & \multirow{2}{*}{1.94} \\
\hline Governance & 1.79 & \\
\hline Partnership & 1.89 & \\
\cline { 1 - 2 } $\begin{array}{l}\text { Scope and } \\
\text { Architecture }\end{array}$ & 2.00 & \\
\hline Expertise & 1.95 & \\
\hline
\end{tabular}

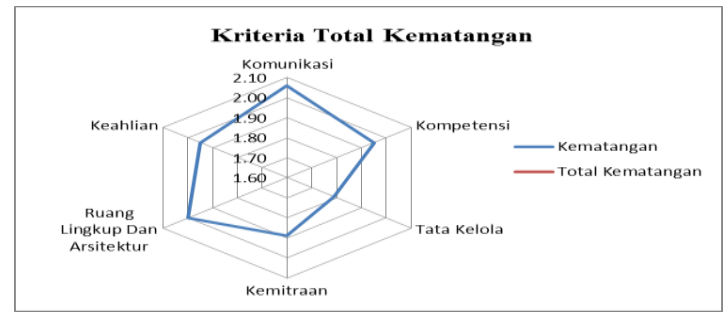

Figure 7

Maturity Criteria

In this condition, the approach used to maintain and improve maturity is based on understanding the maturity level that has been achieved at this time. Based on the assessment carried out in Kelapa Dua sub-district, Kelapa Dua where the author conducted a new research to achieve alignment of business strategy and IT strategy at level 1 (Initial / Ad hoc Process) which could not be said the alignment of current business strategies and IT strategies applied. Which means that the current kelurahan has not concentrated too much on the implementation of IT that can help service activities.

However, the kelurahan must have thought about how to arrange the next steps to reach a higher level of maturity while still making more careful observations of the judgments that have been produced for each maturity criterion. Proposals that can be given to the kelurahan in increasing the maturity of the alignment of business and IT strategies can reach the level / level 2 (Commited Process).

\section{CONCLUSION}

SI or IT Strategic Planning is used to harmonize the needs of business strategies and IT strategies to get added value from an organization in terms of competitive advantage. Based on the results and discussion in the previous chapters and also based on the results of the questionnaire and interviews conducted at the Kelapa Dua Village, some conclusions can be drawn from the results of the research conducted as follows:

1. After the identification process using the Luftman method, overall all the criteria and maturity of the information technology strategy and business strategy in the kelurahan are still at level 2 or at the Commited level so that it can be said that there is no alignment between business strategies and IT strategy.

2. However, in the communication criteria there are a number of things that have started to be done well, among others, have been able to receive innovations or changes that exist and to share knowledge information.

3. To increase the maturity of the alignment of information technology strategies with business strategies can be prioritized based on the results of research and thinking. Suggestions from this research on cooperation with partners are improved, information technology infrastructure and facilities concerning networks, computers, other hardware and software are also increased and information technology improvements are adjusted to market trends and desires and needs in the kelurahan.

4. Conducting further research for the progress of the kelurahan, research on strategic policies in terms of developing information technology and service technology adjusts the development of current services and research on the integration between information technology and service technology.

\section{REFERENCE}

Hajikhani, Alborz. 2013. "Strategic Alignment Analysis between IT-Business Strategies." 5: 528-36.

Handayani, Rani Irma. 2016. "KAJIAN TINGKAT KEMATANGAN KESELARASAN STRATEGI BISNIS DAN TI DENGAN MENGGUNAKAN METODE LUFTMAN STUDI KASUS : PT. BIT TEKNOLOGI 
NUSANTARA." Jurnal Pilar Nusa Mandiri

12(1):

54-61.

http://ejournal.nusamandiri.ac.id/ejurnal/inde

Jogiyanto, $\mathrm{H}$

x.php/pilar/article/view/79 (March 5, 2018).

.M, and Willy Abdillah. 2011. Sistem Tatakelola Teknologi Informasi. Yogyakarta: Andi Offiset.

Luftman, J.N, and T Brier. 1999. Achieving and Sustaining Business-IT Alignment. California Management Review.

Marcel, and Budi Yuwono. 2013. "PENILAIAN TINGKAT KEMATANGAN

KESELARASAN STRATEGI BISNIS DAN TI (STUDI KASUS UNIVERSITAS XYZ)." In Seminar Nasional SIstem Informasi Indonesia, , 2-4. 